\title{
MEMAHAMI PENCITRAAN POLITIK MELALUI PENDEKATAN MEKANISME PERTAHANAN DIRI
}

\author{
Musdalifah Dachrud 1 \\ Aris Soleman ${ }^{2}$ \\ Institut Agama Islam Negeri Manado, Manado, Indonesia \\ musdalifahdachrud@yahoo.com \\ aarissoleman@yahoo.com
}

\begin{abstract}
Political imagery is one way that has the potential to lead and persuade people to political choices. The issue is raised imaging behavior of a politician(candidate) is not necessarily the same as the real character and personality. Defense mechanism is one of the studies in psychology that can provide insight and understanding of the political imagery. Sigmund Freud explained that the defense mechanisms are not conscious effort to show the process that protects the individual from anxiety through the perversion of reality.
\end{abstract}

Keywords: political imagery, defense mechanism

Abstrak. Pencitraan politik merupakan salah satu cara yang berpotensi untuk menggiring dan merayu rakyat terhadap pilihan politiknya. Permasalahannya adalah perilaku pencitraan yang dimunculkan seorang politisi (calon) belum tentu sama dengan karakter dan kepribadian yang sesungguhnya. Mekanisme pertahanan diri (defense mechanism) merupakan salah satu kajian dalam psikologi yang dapat memberikan pandangan dan pemahaman mengenai pencitraan politik. Sigmund Freud menjelaskan bahwa mekanisme pertahanan diri adalah upaya menunjukkan proses tidak sadar yang melindungi individu dari kecemasan melalui pemutarbalikkan kenyataan.

Kata Kunci: pencitraan politik, mekanisme pertahanan diri

\footnotetext{
${ }^{1}$ Dosen Tetap Bidang Ilmu Psikologi pada PPs IAIN Manado dan Wakil Dekan III Fakultas Ushuluddin Adab dan Dakwah

2Dosen Bidang Ilmu Psikologi pada Fakultas Ushuluddin Adab dan Dakwah
} 


\section{Pendahuluan}

Tahun 2015 bisa disebut sebagai tahun politik bagi beberapa daerah yang menyelenggarakan pilkada (pemilihan kepala daerah) di Indonesia. Panggung perpolitikan mulai bergemuruh kembali (setelah tahun 2014) dengan warna juga pesona. Dari mulai sudut-sudut kampung sampai perkotaan, jalan-jalan dihiasi sesak oleh gambar, spanduk, dan baliho partai atau kandidat pasangan calon kepala daerah. Seolah tak ada tempat dan ruang kosong, semuanya nyaris terisi oleh janji dan niat menjadi partai atau kepala daerah terbaik. Menjelang pilkada 2015, semua calon baik pasangan Gubernur, Walikota dan Bupati, berlomba-lomba menampilkan "kesempurnaan" dihadapan masyarakat.

Sering kita lihat dan hadapi para pasangan calon yang bersikap begitu ramah dan murah hati. Sebelum maju dalam pertarungan politik, mungkin kita tak pernah bertemu bahkan tak pernah mendengar nama mereka, lalu mengapa ketika bertemu mereka begitu baik dan seperti mengenal kita dengan dekat. Dalam beberapa kesempatan atau acara tertentu, mereka mendekati, menyapa dan berjabat tangan ke semua tamu yang hadir. Tak sedikitpun mereka lewatkan, tak terkecuali bagi pendukung lawan politiknya. Apakah ini perilaku yang sengaja dibentuk untuk memunculkan citra positif dirinya kepada masyarakat?

Dalam politik, pencitraan selalu identik dengan "show off" pamer, menonjolkan diri maupun partai dengan mengedepankan ideologi, visi, berbagai macam perubahan hingga simbol-simbol tertentu yang akan memudahkan massa pemilih dalam mengingat partai maupun calon tertentu. Politik pencitraan intinya ingin membuat orang lain (pemilih) terpesona, kagum, memunculkan rasa ingin tahu, memunculkan kedekatan yang memang sengaja dibangun demi popularitas. $^{3}$

Permasalahannya adalah pencitraan tidak selalu seiring sejalan dengan kenyataan perilaku yang sesungguhnya. Citra individu dibentuk sedemikian rupa untuk mempengaruhi persepsi individu yang lain. Dalam politik, perilaku yang diperlihatkan seorang calon terhadap masyarakat, belum tentu sama dengan karakter dan kepribadiannya. Politik mampu merubah perilaku seseorang dari yang biasa menjadi luar biasa, dari normal menjadi abnormal. Sering kita temui perilaku seorang politisi tampak seperti ada dorongan (paksaan) yang berlawanan dari yang sesungguhnya. Senyum yang

3 Grendi Hendrastomo, Demokrasi dan politik pencitraan. Jakarta, 2009 
terpaksa, memuji yang terlalu tulus, begitu perhatian, dan perilaku baik tanpa sebab. Hal ini pasti menimbulkan banyak pertanyaan yang kadang mampu terjawab berdasarkan pengalaman yang sudah-sudah.

Dalam psikologi, perilaku individu seperti di atas berkaitan dengan kepribadian. Mekanisme pertahanan diri (defence mechanism) merupakan salah satu kajian dalam psikologi yang bisa memberi gambaran perilaku pencitraan dalam politik. Menurut Sigmund Freud pencetus teori psikoanalisis, menjelaskan bahwa mekanisme pertahanan diri adalah upaya menunjukkan proses tak sadar yang melindungi si individu dari kecemasan melalui pemutarbalikkan kenyataan.

Tulisan ini memaparkan bentukbentuk mekanisme pertahanan diri yang merupakan bagian dari kajian psikologi (psikoanalisis) sebagai upaya untuk memberikan pandangan/paradigma berbeda terhadap kajian politik khususnya fenomena pencintraan politik.

\section{Pengertian Pencitraan Politik}

Citra adalah dunia menurut persepsi kita, atau pictures in our head ${ }^{4}$

4 Water Lippman, Public Opinion, (Jakarta: Yayasan Obor Indonesia, 1965) yang merupakan gambaran tentang realitas, mungkin saja tidak sesuai dengan realitas. Citra terbentuk berdasarkan informasi yang diterima melalui berbagai media, utamanya media massa cetak dan elektronik, yang bekerja membentuk, mempertahankan, atau meredefinisikan citra. Menurut Nimmo, citra adalah segala hal yang berkaitan dengan situasi keseharian seseorang, menyangkut pengetahuan, perasaan dan kecenderungannya terhadap sesuatu. ${ }^{5}$ Sehingga citra dapat berubah seiring dengan perjalanan waktu. Teori image building menyebutkan bahwa, citra akan terlihat atau terbentuk melalui proses penerimaan secara fisik (panca indra), masuk ke saringan perhatian (attention filter), dan dari situ menghasilkan pesan yang dapat dilihat dan dimengerti (perseived message), yang kemudian berubah menjadi persepsi dan akhirnya membentuk citra. ${ }^{6}$

Lebih jauh, Nimmo menyebutkan bahwa, citra seseorang tentang politik yang terjalin melalui pikiran, perasaan dan kesucian subyektif akan memberi

5 Dan Nimmo Dalam Sirajudin, Komunikasi Politik: komunikator, Pesan dan Media, (Bandung: PT. Remaja Rosdakarya, 1993) 2005

6 M Wayne DeLozier, The Marketing Communication Process, Tokyo: McGraw-Hill Kogakushu, Ltd, 1976). 
kepuasan baginya, yang paling tidak memiliki tiga kegunaan, yaitu: ${ }^{7}$

1. Betapapun benar atau salah, lengkap atau tidak lengkap, pengetahuan orang tentang politik, memberi jalan pada seseorang untuk memahami sebuah peristiwa politik tertentu.

2. Kesukaan dan ketidaksukaan umum pada citra seseorang tentang politik menyajikan dasar untuk menilai objek politik.

3. Citra diri seseorang memberikan cara menghubungkan dirinya dengan orang lain. Sebagai bagian dari komunikasi politik, pencitraan politik memang dilakukan secara persuasif untuk memperluas arsiran wilayah harapan antara kandidat dengan pemilih.

Schweiger dan Adami mengemukakan, citra merupakan gambaran menyeluruh yang ada di kepala pemilih mengenai kandidat maupun program. ${ }^{8}$ Kedua penulis ini

\footnotetext{
${ }^{7}$ Nimmo, Op.Cit

8 G Schweiger dan M Adami, The Non Verbal Image of Politicians an Political Practies, (California: Sage, 1999)
}

berpendapat bahwa proses pengambilan keputusan tidak selamanya dipengaruhi oleh pengetahuan pemilih tentang program-program partai maupun oleh informasi-informasi yang membangun brand politik, tetapi proses itu bisa jadi dipengaruhi kuat oleh impression (keterkesanan) dan nonrational evaluation criteria (kriteria yang tidak rasional yang dipakai pemilih dalam mengevaluasi para kandidat/parpol).

Dalam demokrasi, pencitraan menjadi penting karena adanya reprsentasi suara yang disematkan ketika seseorang berlomba-lomba menjadi calon kepala daerah. Seseorang yang ingin menjadi kepala daerah paling tidak harus dikenal oleh massa pemilih dan kepentingan untuk menampilkan sosok dirinya dengan harapan massa pemilih akan memilih dirinya. Konteks kepala daerah sendiri bisa diperdebatkan. Idealnya, semua orang memiliki kans yang sama untuk menjadi kepala daerah. Masyrakat sebagai warga negara biasa mempunyai akses yang sama ke dunia politik. Dalam kenyataanya, akses ini dibagi secara tidak merata. Pembagian itu ditentukan berasarkan tingkat pendidikan, kepemilihan kelompok/agama dan posisi geografis. Ketiga faktor itu mencerminkan besarnya kapital yang 
dimiliki (kapital budaya, sosial ekonomi, dan simbolik). Kepemilikan kapital menentukan hubungan kekuasaan yaitu daya tahan terhadap hak-hak mereka. ${ }^{9}$

Bentuk pencitraan politik yang dilakukan terbagi dalam dua strategi, yaitu Incumbent Vs Challenger. Yang pertama menunjukkan pencapaian sehingga perlu untuk diteruskan. Adapun yang kedua menunjukkan kegagalan-kegagalan kebijakan pemerintah sehingga tema kampanyenya adalah perubahan untuk digantikan secara konstitusional. Dua strategi itulah, pencitraan politik dilakukan untuk meraih simpati dan kepercayaan publik, melalui aneka ragam aksi. ${ }^{10}$

\section{Mekanisme Pertahanan Diri Sigmund} Freud

Pemahaman tentang kesadaran dan ketidaksadaran manusia merupakan salah satu sumbangan terbesar dari pemikiran Freud. Menurutnya, kunci untuk memahami perilaku dan problema kepribadian bermula dari hal tersebut. Ketidakasadaran itu tidak dapat dikaji langsung, karena perilaku yang muncul itu merupakan konsekuensi logisnya. Menurut Corey, bukti klinis untuk membenarkan alam ketidaksadaran

9 Haryatmoko, 2008.

10 Hasan, 2009. manusia dapat dilihat dari hal-hal berikut, seperti: 11

1. mimpi; hal ini merupakan pantulan dari kebutuhan, keinginan dan konflik yang terjadi dalam diri,

2. salah ucap sesuatu; misalnya nama yang sudah dikenal sebelumnya,

3. sugesti pasca hipnotik,

4. materi yang berasal dari teknik asosiasi bebas, dan

5. materi yang berasal dari teknik proyeksi, serta isi simbolik dari simptom psikotik.

Sedangkan kesadaran itu merupakan suatu bagian terkecil atau tipis dari keseluruhan pikiran manusia. Hal ini dapat diibaratkan seperti gunung es yang ada di bawah permukaan laut, dimana bongkahan es itu lebih besar di dalam ketimbang yang terlihat di permukaan. Demikianlah juga halnya dengan kepribadian manusia, semua pengalaman dan memori yang tertekan akan dihimpun dalam alam ketidaksadaran.

Bagian yang tidak kalah penting dari teori Freud adalah tentang kecemasan. Corey mengartikan

11 Gerald Corey, Teori dan Praktek Konseling dan Psikoterapi, (Bandung: PT. Refika Aditama, 2003) 
kecemasan itu adalah sebagai suatu keadaan tegang yang memaksa kita untuk berbuat sesuatu. ${ }^{12}$ Kecemasan ini menurutnya berkembang dari konflik antara sistem id, ego dan superego tentang sistem kontrol atas energi psikis yang ada. Fungsinya adalah mengingatkan adanya bahaya yang datang.

Sedangkan menurut Hall dan Lindzey, kecemasan itu ada tiga: kecemasan realita, neurotik dan moral. ${ }^{13}$

1. kecemasan realita adalah rasa takut akan bahaya yang datang dari dunia luar dan derajat kecemasan semacam itu sangat tergantung kepada ancaman nyata.

2. kecemasan neurotik adalah rasa takut kalau-kalau instink akan keluar jalur dan menyebabkan sesorang berbuat sesuatu yang dapat mebuatnya terhukum, dan

3. kecemasan moral adalah rasa takut terhadap hati nuraninya sendiri. Orang yang hati nuraninya cukup berkembang cenderung merasa bersalah apabila berbuat sesuatu yang

12 Ibid

13 Calvin S Hall dan Lindzey, Gardner, Teori-teori Psikodinamik (Klinis), (Yogyakarta: Kanisius, 1993)

bertentangan dengan norma moral.

Untuk menghadapi tekanan kecemasan yang berlebihan, sistem ego terpaksa mengambil tindakan ekstrim untuk menghilangkan tekanan itu. Tindakan yang demikian itu, disebut mekanisme pertahanan (defence mechanisme) atau mekanisme pertahanan diri. Sebab tujuannya adalah untuk mempertahankan ego terhadap tekanan kecemasan. Dalam teori Freud, bentuk-bentuk mekanisme pertahanan diri adalah sebagai berikut ${ }^{14}$ (lihat tabel):

Tabel : Mekanisme Pertahanan Diri

\begin{tabular}{|c|c|}
\hline $\begin{array}{c}\text { MEKANISME } \\
\text { PERTAHANAN DIRI }\end{array}$ & DESKRIPSI \\
\hline Repression (represi) & $\begin{array}{l}\text { Merupakan } \\
\text { cara } \\
\text { individu } \\
\text { untuk } \\
\text { menekan } \\
\text { perasaan } \\
\text { frustasi, } \\
\text { konflik } \\
\text { batin, mimpi } \\
\text { buruk dan } \\
\text { sejenisnya } \\
\text { yang } \\
\text { menimbulka } \\
\text { n } \\
\text { kecemasan. }\end{array}$ \\
\hline $\begin{array}{l}\text { Displacement } \\
\text { (pengalihan) }\end{array}$ & $\begin{array}{l}\text { Mentransfer } \\
\text { perasaan } \\
\text { kita dari } \\
\text { target } \\
\text { sebenarnya }\end{array}$ \\
\hline
\end{tabular}




\begin{tabular}{|c|c|}
\hline & $\begin{array}{l}\text { (mengancam } \\
\text { ) ke target } \\
\text { pengganti } \\
\text { yang tidak } \\
\text { berbahaya }\end{array}$ \\
\hline Denial (pengingkaran) & $\begin{array}{l}\text { Tidak mau } \\
\text { menolak } \\
\text { untuk } \\
\text { mengakui } \\
\text { (menyangkal } \\
\text { ) aspek } \\
\text { realitas } \\
\text { tertentu }\end{array}$ \\
\hline $\begin{array}{l}\text { Rationalization } \\
\text { (rasionalisasi) }\end{array}$ & $\begin{array}{l}\text { Menemukan } \\
\text { alasan yang } \\
\text { dapat } \\
\text { diterima } \\
\text { untuk } \\
\text { perilaku/sit } \\
\text { uasi yang } \\
\text { tidak dapat } \\
\text { diterima }\end{array}$ \\
\hline $\begin{array}{l}\text { Reaction formation } \\
\text { (pembentukan reaksi) }\end{array}$ & $\begin{array}{l}\text { Individu } \\
\text { melakukan } \\
\text { pembentuka } \\
\text { n reaksi } \\
\text { ketika ia } \\
\text { berusaha } \\
\text { menyembun } \\
\text { yikan motif } \\
\text { dan perasaan } \\
\text { yang } \\
\text { sesungguhn } \\
\text { ya dan } \\
\text { menampilka } \\
\text { n wajah } \\
\text { yang } \\
\text { berlawan } \\
\text { dari ekspresi } \\
\text { yang } \\
\text { sesungguhn } \\
\text { ya }\end{array}$ \\
\hline $\begin{array}{l}\text { Sublimation } \\
\text { (sumblimasi) }\end{array}$ & $\begin{array}{l}\text { Mencegah } \\
\text { dan } \\
\text { meredakan } \\
\text { kecemasan } \\
\text { dengan } \\
\text { merubah }\end{array}$ \\
\hline
\end{tabular}

\begin{tabular}{|c|c|}
\hline & $\begin{array}{l}\text { dorongan } \\
\text { libido ke } \\
\text { arah yang } \\
\text { lebih dapat } \\
\text { diterima }\end{array}$ \\
\hline $\begin{array}{l}\text { Identification } \\
\text { (identifikasi) }\end{array}$ & $\begin{array}{l}\text { Memasukka } \\
\mathrm{n} \text { orang lain } \\
\text { ke dalam } \\
\text { kepribadian } \\
\text { nya sendiri } \\
\text { dan } \\
\text { membuatny } \\
\text { a bagian dari } \\
\text { diri sendiri }\end{array}$ \\
\hline Projection (proyeksi) & $\begin{array}{l}\text { Memindahka } \\
\mathrm{n} \\
\text { perasaan/ke } \\
\text { salahan yang } \\
\text { tidak dapat } \\
\text { diterima } \\
\text { pada orang } \\
\text { lain }\end{array}$ \\
\hline Regression (regresi) & $\begin{array}{l}\text { Kembali ke } \\
\text { perilaku } \\
\text { yang } \\
\text { menjadi ciri } \\
\text { tahap } \\
\text { perkembang } \\
\text { an } \\
\text { sebelumnya }\end{array}$ \\
\hline Isolation (isolasi) & $\begin{array}{l}\text { Memisahkan } \\
\text { pikiran- } \\
\text { pikiran/pera } \\
\text { saan- } \\
\text { perasaan } \\
\text { yang } \\
\text { kontradiktif } \\
\text { ke dalam } \\
\text { komparteme } \\
\text { n- } \\
\text { komparteme } \\
\text { n yang } \\
\text { logictight. }\end{array}$ \\
\hline
\end{tabular}




\section{Pembahasan}

Analisis Pencitraan Politik Melalui Pendekatan Mekanisme Pertahanan Diri

Pada tahun 1921, Harding dinobatkan sebagai presiden Amerika Serikat yang ke 29. Warren Gamaliel Harding adalah sosok yang tampan, memiliki kepala, pundak, dada dengan proporsi yang pas sehingga menimbulkan daya tarik. Sikapnya tegap, langkahnya ringan menunjukkan tubuhnya yang ideal, jantan dan sempurna. Dia santun dan ramah, suka menawarkan kursi duduk sebelum dia menaruh pantatnya, juga memberi tips buat pelayan. Suaranya hangat, maskulin dan menggema. Dia tampil dengan pakaian rapi, sepatu mengkilat dan rambut tertata.

Saat usia 35 tahun, Harry Daugherty, seorang ahli hukum yang cerdas dan pelobi di pemerintah kota Columbia. Saat bertemu ia tertarik melihat penampilan Harding, Daugherty berpikir, orang ini bisa diorbitkan menjadi presiden yang hebat. Lalu sejarah bergulir. Dari seorang editor surat kabar kecil, Harding beranjak menjadi senator, lalu kandidat calon presiden di konvensi Partai Republik. Saat para petinggi Partai Republik putus asa memilih siapa calon yang pantas maju. Harding menyelamatkan lajunya menjadi presiden. Mimpi untuk menjadi presiden terwujud. Walau hanya dua setengah tahun menjadi presiden, Harding menjadi catatan penting dalam sejarah politik dan pemasaran Amerika Serikat.

Walau secara tampilan menyakinkan, Harding memiliki catatan buruk sebagai presiden. Malcolm Gladwell dalam bukunya "Blink", menulis satu bab khusus membahas tentang fenomena Harding. Pada dasarnya Harding bukan orang yang sangat cerdas. Ia peragu dan plin plan. Ia gemar bermain poker, golf, dan minum hingga mabuk. Harding untungnya hanya singkat menjabat presiden, dari Maret 1921 hingga Agustus 1923. Ia meninggal karena stroke. Kebanyakan sejarawan sepakat, Harding adalah salah satu presiden terburuk dalam sejarah Amerika Serikat. ${ }^{15}$

Kesalahan publik Amerika Serikat saat memilih Harding ini disebabkan publik mengkaitkan tampilan fisik dengan karakter tertentu. Publik menilai dengan singkat alias Snap Judgement. Sosoknya yang tegap, dermawan dan sopan dikaitkan dengan sikap yang tegas, baik dan suka menolong. Inilah yang

15 Malcolm Gladwell, Blink (Kemampuan Berpikir tanpa Berpikir), (Jakarta: PT. Gramedia pustaka Utama, 2005). 
disebut Warren Harding Error. Benak kita biasa mengkaitkan satu hal dengan hal lain karena kebiasaan. Karena sosoknya tegap maka dia sikapnya tegas. Karena suka memberi tips maka dia akan membuat kebijakan yang pro rakyat. Terlepas itu semua, Harding dan Daugherty berhasil menggunakan pencitraan sebagai alat untuk memenangkan pertarungan politik. Harding dan Daughetry berhasil mengkampanyekan cara berpikir sederhana dan linear, jika A maka kesimpulannya B.

Cerita di atas memberikan gambaran yang jelas mengenai praktek pencitraan politik serta dampaknya dalam demokrasi. Pencitraan mampu membuat masyarakat terbuai akan tampilan dan janji yang belum teruji. Setiap individu dalam masyarakat pada dasarnya ingin memilih pemimpin yang ideal, memiliki penampilan yang menarik, cerdas, tegas, religius, adil, serta memiliki kepedulian yang tinggi. Partai politik dan kandidat sebagai bagian dari masyarakat mengetahui hal tersebut. Sehingga mereka mendesain "diri" sedemikian rupa untuk tampil sesuai dengan harapan masyarakat agar nantinya dipilih.

Maka tak jarang di baliho atau pamflet kampanye sering kita temui foto caleg memakai peci atau jilbab untuk menunjukkan kesalehannya pada masyarakt pemilih yang mayoritas beragama Islam. Seperti terdakwa yang menunjukkan pertobatannya untuk mengurangi sangsi sosial dari masyarakat. Atau tangan mengepal ke atas untuk menunjukkan sikap tegas yang ditujukan kepada para pemilih pemula. Partai politik pun menggaet tokoh-tokoh tertentu untuk menampilkan image yang baik-baik. Artis muda, tokoh agama, militer dan aktivis. Mereka juga menggelar program agar tampak peduli, penggajian, bantuan sosial, bahkan money politik.

Padahal belum tentu pemimpin dengan latar agama akan mendorong kebijakan sesuai nilai agama. Justru malah ada calon sekuler yang menelorkan kebijakan religius. Calon militer ingin menunjukkan ketegasannya. Padahal pemimpin dari militer, bisa juga plin-plan. Calon kaum muda, untuk menggambarkan perubahan. Padahal tak sedikit politikus muda terjerat kasus korupsi.

Pencitraan adalah kata yang sudah biasa terdengar bahkan tak hanya untuk kepentingan politik praktis saja. Semua orang tak terkecuali, ingin terlihat baik dihadapan orang lain. Sudah menjadi sifat dasar manusia sebagai 
mahkluk sosial yang memiliki akal dan bahasa yang digunakan sebagai alat untuk disenangi oleh lingkungannya. Pencitraan dilakukan untuk membentuk opini publik dan mendorong cara pandang yang baru terhadap sesuatu yang lama dipahami.

Bentuk-bentuk mekanisme pertahanan diri sering dipakai dalam upaya pencitraan individu maupun kelompok untuk kepentingan politik. Terdapat banyak bentuk dalam mekanisme pertahanan diri menurut Freud. Namun dalam pembahasan ini, penulis memfokuskan pada beberapa bentuk mekanisme pertahanan diri yang sering dipraktekkan dalam upaya pencintraan politik.

Bentuk yang pertama adalah Reaction formation (pembentukan reaksi), seseorang melakukan pembentukan reaksi ketika ia berusaha menyembunyikan motif dan perasaan yang sesungguhnya dan menampilkan wajah yang berlawanan dari ekspresi yang sesungguhnya. Mekanisme pertahanan diri seperti ini paling sering kita jumpai dalam dunia politik. Seseorang yang terjun ke dunia politik akan merasa cemas jika masyarakat tak menyukainya. Mereka akan melakukan apa saja untuk meraih simpati masyarakat. Misalnya seorang calon walikota yang terkenal kaya raya, memiliki rumah dan mobil mewah, makan selalu di restaurant yang mahal. Ketika kampanye rela jalan kaki untuk keliling kampung kumuh bahkan makan bersama masyarakat di warung kaki lima. Perilaku seperti ini sebelumnya tidak pernah di lakukan olehnya, jangankan jalan kaki keliling kampung, menggunakan mobilpun mungkin belum pernah dilakukannya. Ada perubahan perilaku dan ekspresi yang dimunculkan demi membentuk persepsi masyarakat terhadap dirinya, sehingga masyarakat akan beranggapan bahwa ia calon pemimpin yang sederhana, peduli terhadap masyarakat miskin dan sebagainya. Sadar atau tidak, ia menyembunyikan perasaan yang sesungguhnya demi kepentingan.

Contoh lain seperti seorang anggota DPR terlihat marah dan tampak garang dengan maraknya perilaku korupsi para anggota DPR dalam suatu rapat di ruang komisi. Ia sangat lantang menyuarakan kebenaran dan keadilan. Sikap penolakan terhadap praktek korupsi begitu menggelora dan berapiapi. Masyarakat yang menonton hal tersebut lewat televisi begitu kagum padanya, seakan-akan sosoknya begitu tegas dan bersih. Beberapa bulan kemudian ia terdakwa dipengadilan 
karena kasus korupsi. Apa yang dilakukannya ketika rapat adalah ekspresi yang tidak sebenarnya, ada hal lain yang sesungguhnya mendorong perilakunya. Ketika melakukan korupsi, ia menyamarkan perilakunya ketika rapat dengan perilaku seakan-akan ia tidak mungkin melakukan hal tersebut. Hal ini membentuk penilaian masyarakat padanya, sehingga ketika ia ditetapkan tersangka oleh KPK, masyarakat membela dan malah menuduh kinerja KPK yang tidak beres.

Mekanisme pertahanan diri reaction formation merupakan bentuk pencintraan yang sulit diidentifikasi. Kita tak pernah dan tak mungkin mengetahui dengan pasti maksud/motif dari perkataan atau perilaku yang dimunculkan seseorang. Terlebih dalam politik, semua perilaku memiliki motif yang sulit di tebak. Hari ini bisa saja bermusuhan, besok sudah tertawa bersama, kemarin ramah sekarang cuek, yang sebenarnya koruptor membentuk opini seorang yang bersih dan sebagainya.

Bentuk yang ke dua adalah Projection (proyeksi) yaitu memindahkan perasaan/kesalahan yang tidak dapat diterima pada orang lain. Semisal, anda dibenci seseorang tapi kemudian orang itu menuduh anda yang membencinya atau sebaliknya. Sama dengan reaction formation, proyeksi begitu sering digunakan dalam pencitraan politik. Coba kita amati beberapa contoh kasus dalam beberapa tahun terakhir yang menggunakan proyeksi sebagai upaya pencitraan. Seorang Gubernur berhasil mengagetkan banyak orang. Program-program yang dilakukan olehnya begitu inovatif dan berbeda. Ia begitu terlihat sempurna dalam menjalankan tanggung jawabnya, dari pekerjaan kecil sampai yang besar diketahui olehnya dengan sangat detail. Beberapa kali dan akhir-akhir ini terlalu sering ia mencopot atau memindahkan bawahannya karena melakukan kesalahan dalam melaksanakan tugas atau pekerjaan yang dilaksanakan bawahan tak sesuai keinginannya. Memang itu adalah hak yang melekat padanya selaku pimpinan. Namun ada kesan bahwa ia seakan-akan melimpahkan kesalahan pada bawahannya. Sebagian masyarakat menganggap bahwa apa yang dilakukan Gubernur adalah benar dan memang seharusnya demikian. Namun tak sedikit juga masyarakat yang berasumsi bahwa keputusan mengganti-ganti pejabat dibawahnya merupakan perilaku yang sengaja dimunculkan untuk menutupi kesalahannya. 
Sebuah partai menuduh partai lain sarang koruptor padahal anggota partai tersebut juga banyak yang tersangkut kasus korupsi, pemerintah menyalahkan pemerintahan sebelumnya ketika ekonomi Negara melemah, dan banyak lagi contoh-contoh yang bisa kita amati baik langsung ataupun tidak. Perilaku proyeksi dalam pencitraan politik dilakukan untuk menjaga nama baik (pencitraan) sebagai individu maupun organisasi.

Bentuk yang ke tiga adalah Repression (represi), merupakan cara individu untuk menekan perasaan frustasi, konflik batin, mimpi buruk dan sejenisnya yang menimbulkan kecemasan. Dalam politik sering kita temui seorang kandidat yang dalam beberapa survey serta kalkulasi dukungan yang dilakukan oleh beberapa lembaga, memprediksikan bahwa kesempatannya untuk menang dalam pertarungan politik begitu kecil. Sang kandidat pada dasarnya sudah mengetahui dan memahami peluangnya untuk menang. Maka untuk menekan perasaannya tersebut, kandidat berusaha meyakinkan diri dan pendukungnya bahwa mereka pasti menang. Hal ini dilakukan sebagai upaya untuk menekan kecemasan yang terjadi dalam batinnya. Ia berusaha bersikap biasa saja, seolah tak merasa cemas dan tampak optimis. Penekanan perasaan yang ada dalam dirinya dilakukan untuk mengurangi dampak kecemasan.

Bentuk yang ke empat adalah Identification (identifikasi), bentuk ini masih memiliki kaitan dengan bentuk represi. Ketika seorang kandidat merasa cemas karena hasil survey yang memprediksi bahwa peluangnya untuk menang sangat rendah, maka ia melakukan beberapa pola perilaku yang mendukung penekanan perasaannya. Indentifikasi merupakan sebuah bentuk mekanisme pertahanan dengan cara memasukkan orang lain ke dalam kepribadiannya sendiri dan membuatnya bagian dari diri sendiri. Sang kandidat yang mengetahui akan kalah berusaha untuk menampilkan dirinya seperti seorang tokoh yang dikagumi oleh masyarakat karena keteguhan dan perjuangannya dalam merebut sebuah kemenangan. Tak jarang di Indonesia, seorang Soekarno menjadi model percontohan bagi banyak politisi. Terutama bagi para calon presiden dan kepala daerah. Dari gaya, penampilan, cara berbicara serta gagasan-gagasan Soekarno di tiru.

Masih banyak bentuk-bentuk mekanisme pertahanan diri yang sering digunakan dalam pencitraan politik. Jika 
kita amati dengan seksama, maka dengan mudah kita dapat mendeteksi bentuk mekanisme pertahanan diri yang sedang dipraktekkan oleh pejabat, partai dan calon tertentu.

\section{Penutup}

Freud menyatakan bahwa mekanisme pertahanan diri melibatkan unsur "penipuan diri".16 Dalam pencitraan politik, unsur penipuan diri sangat berpengaruh pada pembentukan opini masyarakat. Penipuan diri yang dimaksud adalah individu tidak mengubah kondisi obyektif terhadap kondisi tertentu dan hanya mengubah cara individu mempersepsi atau memikirkan kondisi tersebut. Dalam hal ini, partai, pejabat atau calon tertentu, harus pandai memaknai dan memikirkan perilaku dan tindakan yang mereka munculkan untuk memberi kesan positif terhadap pandangan masyarakat.

Pencitraan dalam demokrasi menjadi sesuatu hal yang wajar dan logis, dimana semua memiliki kemungkinan yang sama untuk dipilih. Citra seseorang akan menambah maraknya demokrasi dan membantu tercapainya demokrasi masyarakat, ketika janji-janji yang dicitrakan dan ditampilkan benar-benar mampu

\footnotetext{
16 Freud, Op.Cit
}

membawa perubahan dan kesejahteraan masyarakat.

Namun, perlu dipahami, sekalipun memiliki daya pengaruh yang luar biasa, aktifitas politik yang hanya mengedepankan pencitraan politik, tanpa dibarengi kualitas diri politik, pada akhirnya hanya meretas nihilisme. Corner dan Pels menyebutnya cynicism. ${ }^{17}$

\section{Daftar Pustaka}

Corey, Gerald. 2003. Teori dan Praktek Konseling dan Psikoterapi. Bandung: PT. Refika Aditama.

Corner, John dan Dick, Pels. 2003. Media and The Restyling of Politics: Consumerism ,Celebrity, and Cynicism. London: Sage.

Cottam,Martha L. dkk. 2012. Pengantar Psikologi Politik. Jakarta : Rajawali Pers

DeLozier, M. Wayne. 1976. The Marketing Communication Process. Tokyo: McGraw-Hill Kogakushu, Ltd.

Freud, Sigmund. 2002. Psikoanalisis. Yogyakarta: Ikon.

Gladwell, Malcolm. 2005. Blink (Kemampuan Berpikir Tanpa Berpikir). Jakarta : PT. Gramedia Pustaka Utama

Grosss, Richard. 2010. Psychology (The Science of Mind And Behaviour). Yogyakarta: Pustaka Pelajar

17John Corner dan Pels Dick, Media and The Restyling of Politics: Consumerism, Celebrity and Cynisim, (London: Sage, 2003) 
Hall, Calvin S. dan Lindzey, Gardner. 1993. Teori-Teori Psikodinamik (Klinis).Yogyakarta: Kanisius.

Hendrastomo, Grendi. 2009. Demokrasi dan politik pencitraan. Jakarta.

Lippman, Water. 1965. Public Opinion. Jakarta: Yayasan Obor Indonesia

Nimmo, Dan 1989. Dalam Sirajudin. Komunikasi Politik: Komunikator, Pesan dan media. Bandung: PT. Remaja Rosdakarya 2005.

Pratama, M.H.B. 2006. Mekanisme Pertahahan Ego Tokoh Utama Novel Melanie karya Barbara. (Kajian Psikoanalisis Sigmund Freud). Skripsi tidak diterbitkan. Surabaya: JBSI, Universitas Negeri Surabaya.

Schweiger, G. dan Adami, M. 1999. The Non Verbal image of Politicians And Political Practies. California:Sage. 